\title{
Keefektifan Model Pembelajaran Means Ends Analysis Dengan Strategi Heuristik Terhadap Kemampuan Pemecahan Masalah Matematika
}

\author{
Afidatus Solikah $^{1 *}$, Wulan Izzatul Himmah ${ }^{2}$ \\ ${ }^{1,2}$ Program Studi Tadris Matematika IAIN Salatiga, Indonesia. \\ afidatus.afida@gmail.com
}

\begin{abstract}
Abstrak
Penelitian ini bertujuan untuk mengetahui keefektifan penggunaan model pembelajaran Means Ends Analysis dengan strategi pembelajaran heuristik efektif dalam kemampuan pemecahan masalah matematika siswa kelas VII SMP N 2 Bringin. Metode penelitian ini adalah penelitian kuantitatif jenis eksperimen semu. Desain penelitian yang digunakan adalah pretest posttest control group design. Metode pengambilan sampel menggunakan teknik cluster random sampling dan diperoleh sampel yaitu kelas $\mathrm{VII}_{\mathrm{F}}$ sebagai kelas eksperimen dan kelas $\mathrm{VII}_{\mathrm{E}}$ sebagai kelas kontrol. Teknik pengumpulan data yang digunakan adalah tes dan dokumentasi. Analisis data dilakukan dengan bantuan program SPSS versi 25.0 dengan uji Independent Sampel T Test. Hasil penelitian menunjukkan bahwa model pembelajaran Means Ends Analysis dengan strategi pembelajaran heuristik efektif dalam kemampuan pemecahan masalah matematika siswa kelas VII SMP N 2 Bringin.
\end{abstract}

Kata Kunci: Means Ends Analysis; Strategi Heuristik; Kemampuan Pemecahan Masalah.

\begin{abstract}
This study aims to determine the effectiveness of the use of the Means Ends Analysis learning model with an effective heuristic learning strategy in the mathematical problem solving ability of Grade VII students of SMP N 2 Bringin. This research method is a quantitative type of quasi-experimental research. The research design used was a pretest posttest control group design. The sampling method uses cluster random sampling technique and the sample obtained is class VIIF as an experimental class and class VIIE as a control class. Data collection techniques used are tests and documentation. Data analysis was performed with the help of the SPSS program version 25.0 with the Independent Sample T Test. The results showed that the Means Ends Analysis learning model with an effective heuristic learning strategy in the mathematical problem solving ability of students of class VII SMP N 2 Bringin.
\end{abstract}

Keywords: Means Ends Analysis; Heuristic Strategy; Problem solving skill. 


\section{Jurnal Hipotenusa, 1 (1), Desember 2019}

Afidatus Solikah, Wulan Izzatul Himmah

\section{PENDAHULUAN}

Matematika merupakan salah satu bidang studi yang ada pada semua jenjang pendidikan, mulai dari tingkat sekolah dasar hingga perguruan tinggi. Bahkan matematika diajarkan di taman kanak-kanak secara informal. Matematika menurut Susanto (2013:183) merupakan ide-ide abstrak yang berisi simbolsimbol, maka konsep-konsep matematika harus dipahami terlebih dahulu sebelum memanipulasi simbol-simbol itu. Melihat dari sisi tersebut pada dasarnya dalam pembelajaran matematika sangat penting bagi guru untuk mengetahui karakteristik siswanya agar mempermudah proses belajar mengajar.

Guru dalam pengajaran hendaknya mempertimbangkan kecerdasan dan gaya belajar siswa. Menurut Watson (dalam Safitri, dkk, 2013:156), menyatakan bahwa gaya belajar adalah kunci utama untuk mengembangkan kemampuan berpikir peserta didik. Setiap peserta didik memiliki gaya belajar tersendiri. Oleh karena itu, pendidik hendaknya bervariasi dalam mengajar untuk mengakomodasikan gaya belajar peserta didik yang berbeda. Pembelajaran akan berhasil juga ditentukan oleh kemampuan guru dalam memilih model dan strategi pembelajaran yang akan digunakan.

Seiring berkembangnya zaman, semakin banyak model dan strategi pembelajaran yang menarik dan bervariasi yang dapat mengembangkan kemampuan pemecahan masalah siswa. Hal tersebut merupakan tantangan tersendiri bagi guru agar terus belajar dan tidak asal-asalan dalam memilih model dan strategi pembelajaran khususnya dalam mata pelajaran matematika. Pemilihan model dan strategi pembelajaran sangat besar pengaruhnya terhadap hasil belajar siswa. Mata pelajaran matematika memang sangatlah cocok menggunakan pembelajaran secara kelompok, sebab dengan belajar berkelompok siswa dapat mengutarakan pendapatnya tanpa malu-malu. Teman sebaya sangat besar pula pengaruhnya dalam membantu siswa lain untuk memahamkan materi pelajarannya.

Berdasarkan hasil wawancara yang peneliti lakukan pada Hari Kamis Tanggal 11 April 2019 dengan Bapak Adi Sugiarto, S.Pd. yang merupakan salah satu guru kelas mata pelajaran matematika di Kelas VII SMPN 2 Bringin, mengatakan bahwa "penguasaan materi matematika oleh siswa masih tergolong rendah khususnya dalam pemahaman soal yang berbentuk soal pemecahan masalah. Keseluruhan siswa sudah bisa dibilang aktif namun dalam segi pemahaman materi masih kurang membekas dipikiran siswa, oleh karena itu masih terdapat siswa yang memang kurang dalam kemampuannya memecahkan suatu soal tipe pemecahan masalah. Saya biasanya sesekali setelah materi selesai saya memberikan satu dua soal tipe pemecahan masalah, tapi ya itu namanya siswa juga banyak jadi tingkat kecerdasannya pun juga macam-macam". Guru dalam pelaksanaan pembelajaran telah menerapkan banyak model pembelajaran seperti: game, belajar di luar kelas, serta menggunakan sistem pembelajaran kelompok, akan tetapi masih terdapat siswa yang kemampuan pemecahan msalahnya rendah. Menurut guru hal tersebut terjadi sebab banyak siswa yang memang mayoritas anak pesantren sehingga waktu belajar mereka kurang, malas belajar, tidak suka menghitung, dan lemahnya dalam pemahaman soal uraian maupun soal pemecahan masalah yang menuntut suatu pemahaman konsep dan proses pemecahan masalah yang runtut.

Berdasarkan hal di atas peneliti telah memilih model dan strategi pembelajaran yang cocok untuk meningkatkan kemampuan pemecahan masalah matematika yaitu model pembelajaran Means Ends Analysis (MEA) dan strategi pembelajaran yang sesuai dengan model pembelajaran MEA adalah Strategi Heuristik. Model pembelajaran MEA menurut Huda (2014:295), merupakan strategi yang memisahkan permasalahan yang diketahui (problem state) dan tujuan yang akan dicapai (goal state) yang kemudian dilanjutkan dengan melakukan berbagai cara untuk mereduksi perbedaan yang ada di antara permasalahan dan tujuan. Means berarti 'alat atau cara berbeda yang bisa memecahkan masalah', sementara ends berarti akhir tujuan dari masalah.

Sedangkan heuristic adalah suatu penuntun berupa pertanyaan yang diperlukan untuk menyelesaikan suatu masalah (Nurdin dalam Shoimin, 2014:96). Strategi pembelajaran Heuristik ini terdapat empat langkah yang harus dilakukan, yaitu (1) memahami masalah; (2) merencanakan pemecahannya; menyelesaikan masalah sesuai rencana langkah kedua; (4) memerksa kembali hasil yang diperoleh (looking back) (Shoimin, 2014:97). Berawal dari pengertian tersebut peneliti berharap model pembelajaran MEA dengan strategi pembelajaran heuristik ini dapat melatih 
dan meningkatkan kemampuan pemecahan masalah matematika siswa. Diharapkan pula dengan penggunaan model pembelajaran ini dapat menanggulangi rendahnya kemampuan pemecahan masalah dalam pelajaran matematika di SMP N 2 Bringin.

\section{METODE}

Jenis penelitian yang digunakan dalam penelitian ini adalah jenis penelitian kuantitatif dengan menggunakan metode penelitian Quasi Experimental Design (desain eksperimen semu) dengan desain penelitian pretest-posttest control group design, yang dapat digambarkan pada Tabel 1 berikut:

Tabel 1. Pretest-Posttest Control Group Design

\begin{tabular}{|cc|c|c|}
\hline$R$ & $O_{1}$ & $X$ & $O_{2}$ \\
\hline$R$ & $O_{3}$ & & $O_{4}$ \\
\hline
\end{tabular}

(Sugiyono, 2017:76)

Keterangan:

$\mathrm{R}$ : Kelompok dipilih secara random

$\mathrm{X}$ : Perlakuan model pembelajaran MEA

$\mathrm{O}_{1}$ : Keadaan awal (Pretest) kelas eksperimen

$\mathrm{O}_{2}$ : Hasil akhir (Posttest) kelas eksperimen

$\mathrm{O}_{3}$ : Keadaan awal (Pretest) kelas kontrol

$\mathrm{O}_{4} \quad$ : Hasil akhir (Posttest) kelas kontrol

Menurut Sugiyono (2017:76), dalam pretest-posttest control group design ini terdapat dua kelompok yang dipilih secara random kemudian diberi pretest untuk mengetahui keadaan awal adakah perbedaan antara kelompok eksperimen dengan kelompok kontrol. Pengambilan data dilakukan sebanyak dua kali yaitu tes pertama disebut pretest, hasil dari tes ini dinyatakan baik bila nilai kelompok eksperimen dan kelompok kontrol tidak berbeda secara signifikan. Tes kedua yaitu posttest yang dilakukan setelah perlakuan atau penerapan model pembelajaran.

Penelitian ini dilakukan di SMP Negeri 2 Bringin tepatnya di Jl. Salatiga-Kedungjati No.Km 9, Gemok, Pakis, Bringin, semarang, Jawa Tengah 50772. Waktu penelitian dilaksanakan diawali dengan kegiatan di luar penelitian pada tanggal 11 April 2019 hingga penelitian selesai pada tanggal 10 Mei 2019. Populasi dalam penelitian ini adalah seluruh kelas VII di SMP N 2 Bringin dari kelas VIIA hingga VIIF yang berjumlah 159 siswa. Sampel yang digunakan dalam penelitian adalah kelas VIIE sebagai kelas kontrol dan kelas VIIF sebagai kelas eksperimen. Metode pengambilan sampel yang digunakan adalah cluster random sampling. Teknik cluster random sampling, populasi terlebih dahulu dibagi ke dalam himpunan-himpunan (kelompok satuan, cluster), untuk selanjutnya himpunan-himpunan itulah yang di random (bukan individunya secara sendiri-sendiri). Jika sebuah himpunan atau cluster terpilih, maka seluruh warga himpunannya dijadikan sampel penelitian. Jadi, yang menjadi bahan analisis nantinya bukanlah unit-unit sampling, melainkan kelompok/ clusternya (Baro, 2016:95).

Teknik pengumpulan data dalam penelitian ini menggunakan tes. Alat pengumpul data yang digunakan adalah soal tes kemampuan pemecahan masalah matematika. Pembuatan soal tes kemampuan pemecahan masalah matematika disesuaikan dengan indikator pencapaian materi penelitian yaitu belah ketupat dan layang-layang. Penilaian soal tes disesuaikan dengan acuan penskoran soal kemampuan pemecahan masalah.

Teknik analisis data dalam penelitian ini meliputi 2 tahap analisis data yaitu analisis data tahap awal dan analisis data tahap akhir. Analisis data tahap awal menggunakan nilai PTS seluruh kelas VII keudian dianalisi menggunakan uji normalitas, uji homogenitas, dan uji perbedaan dua rata-rata. Analisis data tahap akhir meliputi uji normalitas, uji homogenitas, dan uji hipotesis. Uji hipotesis dalam penelitian ini terbagi mejadi dua yaitu dengan uji independent sampel $t$ test data posttest dan uji independent sampel t test data peningkatan kemampuan belajar (skor N-gain).

Gain ternormalisasi atau sering disebut $(N$-Gain) biasa digunakan untuk memberikan gambaran umum peningkatan hasil belajar antara sebelum dan sesudah pembelajaran (Sundayana, 2016:151). Hake (dalam Meltzer, 2002:1260) mengembangkan rumus gain ternormalisasi untuk mengukur besarnya peningkatan sebelum dan sesudah pembelajaran dihitung dengan rumus:

Gainternormalisasi $(g)=\frac{(\text { skor posttest }- \text { skor pretest })}{(\text { skor maksimum }- \text { skor pretest })}$

\section{HASIL DAN PEMBAHASAN}

Penelitian dilakukan di kelas kontrol dan kelas eksperimen dengan 4 kali pertemuan pada masing-masing kelas. Teknik pengambilan sampel dalam penelitian ini adalah teknik cluster random sampling dan diperoleh kelas 


\section{Jurnal Hipotenusa, 1 (1), Desember 2019}

Afidatus Solikah, Wulan Izzatul Himmah

VIIE sebagai kelas kontrol dan kelas VIIF sebagar kelas eksperimen.

Data yang digunakan dala penelitian ada dua yaitu data tahap awal dan data tahap akhir. Data tahap awal adalah nilai PTS semester I yag kemudian dilakukan pengujian berupa analisis data tahap awal. Data tahap akhir merupakan data skor pretest dan posttest kemampuan pemecahan masalah matematika yang kemudian dilakukan pengujian beruapa analisis data tahap akhir.

Analisis data tahap awal berupa uji normalitas, uji homogenitas, dan uji perbedaan dua rata-rata. Hasil uji normalitas data awal dapat dilihat pada Tabel 2.

Tabel 2. Hasil Uji Normalitas Data Awal

\begin{tabular}{lcl}
\hline Kelas & $\begin{array}{c}\text { Kolmogorov Smirnov } \\
\text { (Sig.) }\end{array}$ & Keterangan \\
\hline VII_A &, $200^{*}$ & Normal \\
\hline VII_B &, 080 & Normal \\
\hline VII_C &, 146 & Normal \\
\hline VII_D &, $200^{*}$ & Normal \\
\hline VII_E &, $200^{*}$ & Normal \\
\hline VII_F &, $200^{*}$ & Normal \\
\hline
\end{tabular}

Berdasarkan Tabel 2 nilai Sig. pada kelas $\mathrm{VII}_{\mathrm{A}}$ sampai kelas $\mathrm{VII}_{\mathrm{F}}$ lebih dari nilai signifikan 0,05 maka dapat dinyatakan bahwa data nilai PTS kelas $\mathrm{VII}_{\mathrm{A}}$ sampai $\mathrm{VII}_{\mathrm{F}}$ tersebut berdistribusi normal.

Hasil uji homogenitas data awal dapat dilihat pada Tabel 3.

Tabel 3. Hasi Uji Normalitas Data Awal

\begin{tabular}{cc}
\hline & Sig. \\
\hline Based on mean &, 061 \\
\hline
\end{tabular}

Berdasarkan Tabel 3. diperoleh nilai sigifikansi $($ Sig. $)>0,05$ yaitu 0,061 >0,05 maka dapat disimpulkan bahwa data nilai PTS tersebut bersifat homogen.

Data yang diperoleh menunjukkan bahwa semua populasi telah berdistribusi normal dan bersifat homogen maka pemilihan sampel dengan cara cluster random sampling dapat dilakukan. Setelah diundi kelas yang terpilih sebagai sampel dalam penelitian adalah kelas VII $_{\mathrm{E}}$ sebagai kelas kontrol dan kelas VII $_{\mathrm{F}}$ sebagai kelas eksperimen. Pemilihan kelas telah terlaksana selanjutnya melakukan uji perbedaan rata-rata antara kelas kontrol dengan kelas eksperimen.

Uji perbedaan dua rata-rata menggunakan uji Independent Sample T Test. Hasil Hasil uji independent sample t test data awal dapat dilihat pada Tabel 4.
Tabel 4. Hasil Uji Independent Sample T Test Data Awal

\begin{tabular}{cc}
\hline & Sig. (2-tailed) \\
\hline Equal variances assumed &, 769 \\
\hline Berdasarkan Tabel 4 bagian Independent
\end{tabular}

Sample T Test karena nilai Sig. (2-tailed) pada Equal variances assumed > 0,05 yaitu 0,769> 0,05 maka $\mathrm{H}_{0}$ diterima, atau dapat disimpulkan bahwa tidak terdapat perbedaan rata-rata nilai PTS antara kelas $\mathrm{VII}_{\mathrm{E}}$ dengan kelas $\mathrm{VII}_{\mathrm{F}}$. Hal ini berarti kedua kelompok sampel memiliki kemampuan awal yang sama.

Analisis data tahap akhir meliputi uji normalitas, uji homogenitas, dan uji hipotesis. Uji hipotesis dalam penelitian ini terbagi mejadi dua yaitu dengan uji independent sampel t test data posttest dan uji independent sampel t test data peningkatan kemampuan belajar (skor $\mathrm{N}$ gain).

Uji normalitas pada data akhir ini digunakan pada nilai pretest, posttest, dan $\mathrm{N}$ gain baik kelas kontrol maupun kelas eksperimen. Hasil uji normalitas dapat dilihat pada Tabel 5 berikut.

Tabel 5. Hasil Uji Normalitas Data Tahap Akhir

\begin{tabular}{lcl}
\hline \multicolumn{1}{c}{ Kelas } & $\begin{array}{c}\text { Kolmogorov- } \\
\text { Smirnov (Sig.) }\end{array}$ & Keterangan \\
\hline $\begin{array}{l}\text { Pretest } \\
\text { Eksperimen }\end{array}$ &, $200^{*}$ & Normal \\
\hline $\begin{array}{l}\text { Posttest } \\
\text { Eksperimen }\end{array}$ &, 105 & Normal \\
\hline $\begin{array}{l}\text { Pretest } \\
\text { Kontrol }\end{array}$ &, $200^{*}$ & Normal \\
\hline $\begin{array}{l}\text { Posttest } \\
\text { Kontrol }\end{array}$ &, 093 & Normal \\
\hline $\begin{array}{l}\text { N-Gain } \\
\text { Kontrol }\end{array}$ &, 171 & Normal \\
\hline $\begin{array}{l}\text { N-Gain } \\
\text { Eksperimen }\end{array}$ &, $200^{*}$ & Normal \\
\hline
\end{tabular}

Berdasarkan Tabel 5 diperoleh hasil uji normalitas data pretest, posttest, dan N-gain pada kelas $\mathrm{VII}_{\mathrm{E}}$ dan kelas $\mathrm{VII}_{\mathrm{F}}$. Perhatikan pada Sig. di bagian Kolomogorov-Smirnov, dari perhitungan uji homogenitas diperoleh bahwa dari keenam data tersebut nilai Sig. lebih dari nilai alfa $(0,05)$, maka dapat dinyatakan bahwa data nilai pretest, posttest, dan N-gain kelas kontrol maupun eksperimen tersebut berdistribusi normal.

Uji homogenitas digunakan untuk mengetahui apakah data dari kedua sampel penelitian bersifat homogen atau tidak. Uji homogenitas data akhir dilakukan dua kali yaitu pertama untuk data posttest kelas kontrol dan eksperimen dan yang kedua yaitu data N-gain kelas kontrol dan kelas eksperimen. 
Uji homogenitas yang pertama adalah menggunakan skor posttest. Data hasil uji homogenitas skor posttest kelas kontrol $\left(\mathrm{VII}_{\mathrm{E}}\right)$ dan skor posttest kelas eksperimen $\left(\mathrm{VII}_{\mathrm{F}}\right)$ dapat dilihat pada Tabel 6 berikut.

Tabel 6. Hasil Uji Homogenitas Skor Posttest Kelas Kontrol dan Eksperimen

\begin{tabular}{cc}
\hline $\begin{array}{c}\text { Kemampuan Pemecahan } \\
\text { Masalah }\end{array}$ & Sig. \\
\hline Based on Mean & $\mathbf{, 0 4 0}$ \\
\hline
\end{tabular}

Karena nilai sigifikansi (Sig.) pada Based on Mean < 0,05 yaitu $0,040<0,05$ maka $\mathrm{H}_{0}$ ditolak, artinya data skor posttest kelas kontrol dan skor posttest kelas eksperimen tersebut bersifat tidak homogen.

Uji homogenitas yang kedua adalah menggunakan skor $\mathrm{N}$-gain. Data hasil uji homogenitas skor $\mathrm{N}$-gain kelas kontrol $\left(\mathrm{VII}_{\mathrm{E}}\right)$ dan skor $\mathrm{N}$-gain kelas eksperimen $\left(\mathrm{VII}_{\mathrm{F}}\right)$ dapat dilihat pada Tabel 7 berikut.

Tabel 7. Hasil Uji Homogenitas Skor N-Gain Kelas Kontrol dan Eksperimen

\begin{tabular}{cc}
\hline $\begin{array}{c}\text { Kemampuan Pemecahan } \\
\text { Masalah }\end{array}$ & Sig. \\
\hline Based on Mean & $\mathbf{1 2 9}$ \\
\hline
\end{tabular}

Karena nilai sigifikansi (Sig.) pada Based on Mean > 0,05 yaitu 0,129>0,05 maka $\mathrm{H}_{0}$ diterima artinya data skor $\mathrm{N}$-gain kelas kontrol dan skor $\mathrm{N}$-gain kelas eksperimen tersebut bersifat homogen.

Uji hipotesis dalam penelitian ini terbagi mejadi dua yaitu dengan uji independent sampel $t$ test data posttest dan uji independent sampel $t$ test data peningkatan kemampuan belajar (skor $\mathrm{N}$-gain). Independent samples $t$ test atau uji perbedaan dua rata-rata digunakan untuk menguji dua rata-rata pada dua kelompok data yang independen.

Uji hipotesis pertama peneliti menggunakan uji Independent $T$ Test data posttest. Hasil uji independent sampel t test data posttest dapat dilihat pada Tabel 8 berikut.

Tabel 8. Hasil Uji independent sampel t test data posttest

t-test for Equality of

Equal variances not

Sig. (2-tailed) assumed

Uji homogenitas skor posttest diperoleh hasil bahwa skor posttest untuk kelas kontrol dan kelas eksperimen bersifat tidak homogen. Oleh karena itu untuk menguji perbedaan ratarata skor posttest dapat dilihat pada Tabel 8 bagian Equal variances not assumed. Karena nilai Sig. (2-tailed) pada Equal variances not assumed $<0,05$ yaitu $0,005<0,05$ maka $\mathrm{H}_{0}$ ditolak artinya terdapat perbedaan rata-rata skor posttest antara kelas kontrol $\left(\mathrm{VII}_{\mathrm{E}}\right)$ dengan kelas eksperimen $\left(\mathrm{VII}_{\mathrm{F}}\right)$.

Besar perbedaan rata-rata skor posttest dapat dilihat pada Tabel 9 berikut:

Tabel 9 Besar Perbedaan Rata-Rata Skor Posttest

\begin{tabular}{lcc}
\hline Kelas & N & Mean \\
\hline Posttest Ekperimen & 25 & 81,04 \\
\hline Posttest Kontrol & 25 & 72,32 \\
\hline \multicolumn{1}{c}{ Berdasan }
\end{tabular}

Berdasarkan pada tabel 9 dapat diketahui besarnya perbedaan antara kelas kontrol dan eksperimen yaitu rata-rata skor posttest kelas kontrol adalah 72,32 dan rata-rata skor posttest kelas eksperimen adalah 81,04. Terlihat bahwa rata-rata skor posttest kelas eksperimen lebih dari nilai KKM yang ditetapkan yaitu 81,04 > 76. Hal ini berarti posttest kelas eksperimen lebih baik dari kelas kontrol.

Uji hipotesis kedua peneliti menggunakan uji Independent $T$ Test skor $N$-Gain kelas kontrol dan eksperimen. Hasil uji independent sampel $t$ test skor $\mathrm{N}$-Gain dapat dilihat pada Tabel 10 berikut.

Tabel 10. Hasil Uji independent sampel t test Skor $N$-Gain

t-test for Equality of

\begin{tabular}{cc} 
& Sig. (2-tailed) \\
\hline $\begin{array}{c}\text { Equal variances } \\
\text { assumed }\end{array}$ & $\mathbf{0 0 1}$ \\
\hline Uji &
\end{tabular}
hasil bahwa skor N-gain untuk kelas kontrol dan kelas eksperimen bersifat homogen. Oleh karena itu untuk menguji perbedaan rata-rata skor $\mathrm{N}$ gain dapat dilihat pada Tabel 10 bagian Equal variances assumed. Berdasarkan Tabel 4.20 diiperoleh nilai Sig. (2-tailed) $<\alpha$ yaitu $0,001<$ 0,05 . Karena $0,001<0,05$ maka $\mathrm{H}_{0}$ ditolak, yang artinya terdapat perbedaan rata-rata peningkatan kemampuan pemecahan masalah kelas kontrol dengan kelas eksperimen.

Besar perbedaan rata-rata peningkatan kemampuan pemecahan masalah kelas kontrol dan kelas eksperimen dapat dilihat pada Tabel 11 berikut.

Tabel 11. Rata-Rata Peningkatan Kemampuan Pemecahan Masalah

\begin{tabular}{clcc}
\hline & N_Gain & N & Mean \\
\hline \multirow{2}{*}{ Skor } & $\begin{array}{l}\text { N-Gain Kelas } \\
\text { Eksperimen }\end{array}$ & 25 & $\mathbf{7 2 3 4 8}$ \\
\cline { 2 - 4 } N_Gain & $\begin{array}{l}\text { N-Gain Kelas } \\
\text { Kontrol }\end{array}$ & $\mathbf{2 5}$ & $\mathbf{5 8 5 8 4}$ \\
\hline
\end{tabular}

Berdasarkan pada Tabel 11 diperoleh bahwa mean untuk skor N-gain kelas kontrol 
adalah 0,58584 yang mana menurut kriteria gain ternormalisasi termasuk dalam kategori sedang dan mean untuk skor $\mathrm{N}$-gain kelas eksperimen adalah 0,72348 yang mana menurut kriteria gain ternormalisasi termasuk dalam kategori tinggi. Hal ini berarti peningkatan kemampuan pemecahan masalah kelas eksperimen lebih baik dari kelas kontrol.

Penelitian ini dilaksanakan dengan tujun utuk mengetahui keefektifan model pembelajaran Means Ends Analysis (MEA) dengan strategi pembelajaran heuristik terhadap kemampuan pemecahan masalah matematika siswa kelas VII SMP N 2 Bringin. Pelaksanaan penelitian ini banyak sampel yang dipakai adalah 50 siswa yaitu 25 siswa dari kelas kontrol $\left(\mathrm{VII}_{\mathrm{E}}\right)$ dan 25 siswa dari kelas eksperimen $\left(\mathrm{VII}_{\mathrm{F}}\right)$

Penelitian ini termasuk penelitian eksperimen tipe quasi eksperimen karena penelitian ini bertujuan untuk mengetahui keefektifan suatu perlakukan (treatment) tertentu pada kelas eksperimen. Prosedur yang peneliti lakukan dalam penelitian ini adalah memberikan pengajaran dengan menggunakan model pembelajaran Means Ends Analysis (MEA) dengan strategi pembelajaran heuristik untuk mengetahui kemampuan pemecahan masalah matematika siswa. Penelitian pada tahap awal peneliti memberikan soal pretest yang bertujuan untuk mengetahui kemampuan awal siswa dalam materi belah ketupat dan layang-layang dengan mengerjakan soal tipe pemecahan masalah. Kemudian setelah pretest pada pertemuan berikutnya peneliti mengajarkan materi belah ketupat dan layang-layang dimana pada kelas kontrol menggunakan model pembelajaran konvensional sedangkan kelas eksperimen menggunakan model pembelajaran Means Ends Analysis (MEA) dengan strategi pembelajaran heuristik. Tahap akhir penelitian, peneliti memberikan soal posttest untuk mengetahui kemampuan pemecahan masalah matematika siswa mengenai materi belah ketupat dan layang-layang.

Berkaitan dengan soal pretest dan posttest, peneliti memberikan 5 soal tipe pemecahan masalah yang telah di uji validitas dan reliabilitasnya. Hasil dari skor pretest dan posttest selanjutnya dianalisis untuk mengetahui efektivitas dari model pembelajaran Means Ends Analysis (MEA) dengan strategi pembelajaran heuristik.

Berdasarkan pada hasil uji hipotesis pertama menggunakan uji independent sample $t$ test pada skor posttest kelas ekperimen diperoleh hasil bahwa nilai Sig. (2-tailed) pada Equal variances not assumed $<0,05$ yaitu 0,005 $<0,05$ maka $\mathrm{H}_{0}$ ditolak artinya terdapat perbedaan rata-rata skor posttest antara kelas kontrol $\left(\mathrm{VII}_{\mathrm{E}}\right)$ dengan kelas eksperimen $\left(\mathrm{VII}_{\mathrm{F}}\right)$. Besarnya perbedaan rata-rata skor posttest antara kelas kontrol dan eksperimen yaitu ratarata skor posttest kelas kontrol adalah 72,32 dan rata-rata skor posttest kelas eksperimen adalah 81,04 . Terlihat bahwa rata-rata skor posttest kelas eksperimen lebih dari nilai KKM yang ditetapkan yaitu 81,04 > 76 .

Berdasarkan pada hasil uji hipotesis kedua menggunakan uji independent sample $t$ test skor $\mathrm{N}$-gain. Uji homogenitas skor $\mathrm{N}$-gain diperoleh hasil bahwa skor $\mathrm{N}$-gain untuk kelas kontrol dan kelas eksperimen bersifat homogen. Oleh karena itu untuk menguji perbedaan ratarata skor N-gain dapat dilihat pada bagian Equal variances assumed yang mana diperoleh nilai Sig. (2-tailed) $<\alpha$ yaitu $0,001<0,05$. Karena $0,001<0,05$ maka $\mathrm{H}_{0}$ ditolak, yang artinya terdapat perbedaan rata-rata peningkatan kemampuan pemecahan masalah kelas kontrol dengan kelas eksperimen. Besar perbedaan ratarata peningkatan kemampuan pemecahan masalah kelas kontrol dan kelas eksperimen yaitu rata-rata untuk skor $\mathrm{N}$-gain kelas kontrol adalah 0,58584 yang mana menurut kriteria gain ternormalisasi termasuk dalam kategori sedang dan mean untuk skor $\mathrm{N}$-gain kelas eksperimen adalah 0,72348 yang mana menurut kriteria gain ternormalisasi termasuk dalam kategori tinggi. Melihat dari hasil uji hipotesis pertama dan uji hipotesis kedua, artinya bahwa model pembelajaran Means Ends Analysis (MEA) dengan strategi pembelajaran heuristik terbukti efektif dalam kemampuan pemecahan masalah matematika siswa kelas VII SMP Negeri 2 Bringin.

Hasil dari penelitian ini bersesuaian dengan hasil penelitian yang dilakukan oleh Ratna Dewi (2013) yang berjudul "Pengaruh Penerapan Strategi Heuristik Model Polya Terhadap Kemampuan Pemecahan Masalah Matematika Siswa SMP Negeri 2 Pekanbaru" bahwa pembelajaran dengan menggunakan strategi heuristik model polya dapat meningkatkan kemampuan pemecahan masalah matematika siswa. Kemudian penelitian yang dilakukan oleh Hilmansyah (2017) dalam penelitiannya yang berjudul "Pengaruh Strategi Means-Ends Analysis Terhadap Kemampuan Berpikir Kreatif Matematis Siswa" dan 
diperoleh kesimpulan bahwa kemampuan berpikir kreatif matematis siswa yang menerapkan strategi Means-Ends Analysis lebih baik daripada siswa yang menggunakan pembelajaran konvensional.

Setelah peneliti menggabungkan antara strategi heuristik dengan model pembelajaran Means-Ends Analysis terhadap kemampuan pemecahan masalah matematika ternyata diperoleh hasil bahwa penerapan model pembelajaran Means Ends Analysis (MEA) dengan strategi pembelajaran heuristik terbukti efektif dalam kemampuan pemecahan masalah matematika siswa kelas VII di SMP Negeri 2 Bringin.

Hal tersebut dapat dilihat dari hasil analisis data yang telah dilaksanakan serta reaksi siswa saat peneliti menerapkan model pembelajaran Means Ends Analysis (MEA) dengan strategi pembelajaran heuristik, yang mana siswa menjadi lebih aktif, lebih percaya diri dalam menyampaikan pendapat ataupun pada saat bertanya hal-hal yang belum dipahami. Siswa lebih menghargai pendapat teman sekelompoknya dan teman lain yang sedang mempresentasikan hasil diskusi kelompoknya. Tertanam pemahaman konsep yang lebih

\section{SIMPULAN}

Berdasarkan dari hasil analisis data yang telah dilakukan, peneliti menyimpulkan bahwa penerapan model pembelajaran Means Ends Analysis (MEA) dengan strategi pembelajaran heuristik terbukti efektif dalam kemampuan pemecahan masalah matematika siswa kelas VII SMP Negeri 2 Bringin karena memenuhi kriteria keefektifan pembelajaran yaitu: 1) Hasil penelitian menunjukkan bahwa terdapat perbedaan rata-rata posttest yang signifikan pada kemampuan pemecahan masalah matematika siswa kelas VII SMP $\mathrm{N} 2$ antara yang menggunakan model pembelajaran Means Ends Analysis (MEA) dengan strategi pembelajaran heuristik dan model pembelajaran konvensional, dimana rata-rata posttest kelas eksperimen lebih dari kelas kontrol. 2) Hasil penelitian menunjukkan bahwa terdapat perbedaan ratarata peningkatan kemampuan pemecahan masalah matematika siswa kelas VII SMP N 2 Bringin antara yang menggunakan model pembelajaran Means Ends Analysis (MEA) dengan strategi pembelajaran heuristik dan model pembelajaran konvensional, dimana ratarata peningkatan kemampuan pemecahan mendalam karena dalam penelitian ini peneliti menggunakan contoh-contoh yang kontekstual sehingga siswa lebih mudah dalam memahami materi yang diajarkan. Disamping itu peneliti juga menerapkan strategi heuristik dimana strategi ini berisi tentang pertanyaan yang menuntun, agar siswa lebih terarah saat pembelajaran dan sejalan dengan tujuan pembelajaran yang akan dicapai.

Adapun keterbatasan peneliti dalam penerapan model pembelajaran Means Ends Analysis (MEA) dengan strategi pembelajaran heuristik baik dari segi waktu, tenaga maupun biaya maka hasil penelitian ini masih perlu disempurnakan. Keterbatasan yang penulis maksud adalah pada penerapan model dan strategi saat perlakuan pertama peneliti masih kekurangan waktu sebab harus menjelaskan dengan detail langkah-langkah pembelajarannya, masih ada beberapa siswa yang masih bingung dengan cara pembelajarannya, sehingga harus dituntut lagi. Namun tetap terselesaikan sesuai dengan RPP yang telah disusun. Pada perlakuan kedua siswa sudah memahami model dan strategi yang dipakai, sehingga proses pembelajaran berjalan dengan lancar.

masalah matematika siswa kelas eksperimen lebih baik dari kelas kontrol.Simpulan dapat bersifat generalisasi temuan sesuai permasalahan penelitian, dapat

\section{DAFTAR PUSTAKA}

Baro, Rachmad. 2016. Penelitian Hukum NonDoktrinal Trend Penggunaan Metode dan Teknik Penelitian Sosial di Bidang Hukum, Ed. 1, Cet. 1. Yogyakarta: Deepublish.

Dewi, Ratna. (2013). Pengaruh Penerapan Strategi Heuristik Model Polya Terhadap Kemwmpuan Pemecahan Masalah Matematika Siswa SMP Negeri 2 Pekanbaru. Skripsi (Online). Program Studi Pendidikan Matematika. Fakutas Tarbiyah Dan Keguruan. Universitas Islam Negeri Sultan Syarif Kasim Riau Pekanbaru. (http://repository.uinsuska.ac.id/2140/1/2013 2013824PMT. pdf diakses 20 Juni 2019).

Hilmansyah. (2017). Pengaruh Strategi MeansEnds Analysis Terhadap Kemampuan 
Berpikir Kreatif Matematis Siswa. Skripsi (Online), Jurusan Pendidikan Matematika, Fakultas Ilmu Tarbiyah dan Keguruan, Universitas Islam Syarif Hidayatullah Jakarta, (http://repository.uinjkt.ac.id/dspace/bits tream/123456789/34561/1/skripsi\%20M EA\%20watermark.pdf, diakses pada 01 April 2019)

Huda, Miftahul. 2014. Model-Model Pengajaran dan Pembelajaran: Isu-Isu Metodis dan Paradigmatis. Yogyakarta: Pustaka Pelajar.

Meltzar, David. E., 2002. The Relationship Between Mathematics Preparation and Conceptual Learning Gains in Physics: a Possible "Hidden Variable" In Diagnostic Pretest Scores. Department of Physics and Astronomy, Iowa State University, Ames, Iowa 50011, (online), Am. J. Phys., Vol. 70, No. 12, (http://ojps.aip.org/ajp/, diakses 17 Juni 2019).

Safitri, dkk. (2013). Pengaruh Pendekatan Multiple Intelligences Melalui Model
Pembelajaran Langsung Terhadap Sikap dan Hasil Belajar Kimia Peserta Didik di SMA Negeri I Tellu Limpoe. Jurnal Pendidikan IPA Indonesia, (Online), Vol. 2, No. 2, (https://journal.unnes.ac.id/nju/index.ph p/jpii/article/view/2717, diakses pada 21 Maret 2019).

Shoimin, Aris. 2014. 68 Model Pembelajaran Inovatif dalam Kurikulum 2013 Cet. 1. Yogyakarta: Ar-Ruzz Media.

Sugiyono. 2017. Metode Penelitian Kuantitatif, Kualitatif, dan $R \& D$, Cet. 26. Bandung: Alfabeta.

Sundayana, Rostina. 2016. Statistika Penelitian Pendidikan: Pembahasan dilengkapi dengan Bantuan MS. Excel dan SPSS, Cet. 3. Bandung: Alfabeta.

Susanto, Ahmad. (2013). Teori Belajar dan Pembelajaran di Sekolah Dasar, Ed. 1, Cet. 1. Jakarta: Kencana. 